Syntax Literate: Jurnal Ilmiah Indonesia p-ISSN: 2541-0849

e-ISSN: 2548-1398

Vol. 6, No. 3, Maret 2021

\title{
PERBANDINGAN TABEL MORTALITA INDONESIA DAN TABEL MORTALITA CSO MENGGUNAKAN UJI MANN-WHITNEY DAN UJI KRUSKAL-WALLIS
}

\section{Handayani Utomo}

Universitas Gunadarma, Indonesia

Email: nday.cools@gmail.com

\section{Abstract}

Mortality tables or life tables are very important instruments in actuarial, demographic and epidemiological studies. Some countries are known to have built up their own mortality tables. So far Indonesia has four mortality tables. This paper examines whether the four Indonesian mortality tables represent real demographic changes in the average mortality rate represented by each of the mortality tables. Using the Mann-Whitney and Kruskal-Wallis nonparametric tests, it was concluded that the four Indonesian mortality tables did not show any significant difference in the average mortality rate. For comparison, the same test was carried out on three US mortality tables with varied results. The nonparametric test between one of the mortality tables belonging to Indonesia and the United States also did not show any significant difference in the average mortality rate.

Keywords: mortality table; nonparametric tests; Mann-Whitne; Kruskal-Wallis.

\begin{abstract}
Abstrak
Tabel mortalita atau life table merupakan instrumen yang sangat penting pada studi aktuaria, demografi dan epidemiologi. Beberapa negara diketahui sudah membangun tabel mortalitanya sendiri. Indonesia sejauh ini sudah memiliki empat tabel mortalita. Paper ini menguji apakah keempat tabel mortalita Indonesia itu mewakili perubahan demografis yang nyata pada rata-rata tingkat kematian yang direpresentasikan oleh masing-masing tabel mortalita. Menggunakan uji nonparametrik Mann-Whitney dan Kruskal-Wallis diperoleh kesimpulan keempat tabel mortalita milik Indonesia tidak menunjukkan perbedaan yang nyata pada ratarata tingkat kematian. Sebagai perbandingan dilakukan uji yang sama pada tiga tabel mortalita milik Amerika Serikat dengan hasil yang bervariasi. Uji nonparametrik antara salah satu tabel mortalita milik Indonesia dan Amerika Serikat juga tidak menunjukkan perbedaan yang nyata pada rata-rata tingkat kematian.
\end{abstract}

Kata kunci: tabel mortalita; uji nonparametric; Mann-Whitney; Kruskal-Wallis 


\section{Coresponden Author}

Email: nday.cools@gmail.com Artikel dengan akses terbuka dibawah lisensi

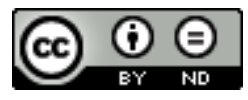

\section{Pendahuluan}

Tabel mortalita atau sering disebut dengan life table merupakan instrumen utama yang dipergunakan oleh aktuaris dalam membangun struktur premi dan cadangan produk-produk asuransi jiwa, anuitas dan program pension (Pitacco, 2014). Tabel mortalita merepresentasikan sebuah skema yang menggambarkan data mortalita dalam bentuk probabilitas (Smith \& Keyfitz, 2012) dan merangkum ide sederhana bahwa pengaruh mortalita yang secara gradual menyusutkan populasi dapat disajikan dalam bentuk tabulasi .

Peran tabel mortalita tidak hanya penting dalam bidang ilmu aktuaria. Tabel mortalita merupakan perangkat kerja tradisional dalam bidang ilmu demografi (Tesárková \& Kurtinová, 2018) dan memiliki peran penting dalam bidang ilmu epidemiologi (Skiadas \& Skiadas, 2018). Dalam demografi, life table sering digunakan untuk keperluan deskriptif dalam rangka membandingkan tingkat mortalita pada usia, jenis kelamin, ras, waktu dan tempat yang berbeda (Thomas, 2018), sedangkan epidemiologis menggunakan life table untuk menentukan faktor-faktor risiko yang berhubungan dengan tingkat morbidita dan mortalita (Wunsch, Mouchart, \& Duchêne, 2013).

Pembentukan tabel mortalita melibatkan pemodelan matematika dan statistika yang tidak sederhana (Macdonald, Richards, \& Currie, 2018). Aktuaris harus memodelkan durasi kehidupan manusia yang merupakan variabel acak menjadi tabel yang mudah dipahami dan digunakan (Khmaladze, 2013). Kenyataan tersebut berimplikasi pada penggunaan tabel mortalita milik negara lain oleh negara yang belum memiliki tabel mortalitanya sendiri menjadi lazim dilakukan. Diperlukan penelitian untuk membandingkan antar tabel mortalita agar penggunaannya tepat secara statistika. Sepanjang yang penulis ketahui belum pernah dilakukan pengujian seperti yang dipaparkan pada paper ini.

Dalam kurun waktu 3 dekade, Indonesia telah memiliki 4 tabel mortalita yang dikenal dengan nama Tabel Mortalita Indonesia (TMI), dengan TMI IV sebagai tabel mortalita terbaru yang dirilis pada Oktober 2019. Sesuai perubahan yang terus menerus terjadi pada struktur demografi (Lundquist, Anderton, \& Yaukey, 2014), tabel mortalita memang perlu diperbarui, namun demikian perlu diuji apakah tabel mortalita yang terbaru sudah menggambarkan perubahan tingkat kematian secara signifikan. Paper ini akan menguji keempat tabel mortalita yang dimiliki oleh Indonesia (TMI I, TMI II, TMI III, dan TMI IV) untuk memperoleh jawaban atas pertanyaan, apakah keempat tabel mortalita indonesia memiliki tingkat kematian rata-rata yang berbeda secara nyata. 
Sebagai pembanding, uji yang sama juga dilakukan pada tabel mortalita Commissioners Standard Ordinary, CSO 1941, CSO 1958, dan CSO 1980 milik Amerika Serikat.

\section{Metode Penelitian}

Metode pengujian dilakukan dengan cara merata-ratakan tingkat kematian $\mathrm{q}_{\mathrm{x}}$ pada masing-masing tabel mortalita untuk kemudian diuji secara nonparametrik untuk menguji hipotesis apakah rata-rata tingkat kematian antara tabel mortalita yang dibandingkan berbeda secara nyata. Uji Mann-Whitney U (mengambil nama Henry Berthold Mann dan Donald Ransom Whitney) (Dickhaus, 2018) digunakan untuk membandingkan rata-rata tingkat kematian dua tabel mortalita. Uji Kruskal-Wallis H (mengambil nama William Kruskal dan Wilson Allen Wallis) (Siebert \& Siebert, 2017) dan uji one way ANOVA on rank digunakan untuk membandingkan rata-rata tingkat kematian lebih dari dua tabel mortalita.

Data tingkat kematian dalam tabel mortalita termasuk tabel mortalita CSO dan TMI tidak mengikuti distribusi normal dan distribusi lainnya atau distribution free dan nonparametrik (Collett, 2015). Tabel mortalita juga mengasumsikan homogenitas kelompok dimana semua subyek yang diamati memiliki distribusi survival times yang sama (Hair, Anderson, Babin, \& Black, 2019). Untuk data yang tidak mengikuti distribusi normal dan distribusi lainnya atau distribution free, uji statistik yang tepat digunakan adalah uji statistik nonparametrik (Hollander, Wolfe, \& Chicken, 2013).

\section{Hasil dan Pembahasan}

Hipotesa 1 diuji menggunakan uji Kruskal-Wallis $\mathrm{H}$ untuk k-independent samples dan uji one way ANOVA on rank dengan tingkat risiko $\alpha=0,05$. Kriteria pengujian pada uji Kruskal-Wallis $\mathrm{H}$ adalah jika $\mathrm{p}$-value $\leq \alpha$, maka $\mathrm{H} 0$ ditolak dan jika tingkat pvalue $\geq \alpha$, maka H0 diterima (Corder \& Foreman, 2014). Dari uji Kruskal-Wallis H dan one way ANOVA on rank diperoleh hasil sebagai berikut:

\section{Tabel 1}

Hasil Uji Kruskal-Wallis $\mathbf{H}$ atas Hipotesis 1

\begin{tabular}{|c|c|c|}
\hline A & $p$-value & Keputusan \\
\hline 0,05 & 0,236 & $\mathrm{H}_{0}$ diterima \\
\hline \multicolumn{3}{|c|}{$\begin{array}{c}\text { Tabel } 2 \\
\text { Hasil Uji one way ANOVA on rank atas Hipotesis } 1\end{array}$} \\
\hline F Hitung & $\begin{array}{c}\text { F Tabel } \\
(\mathrm{df} 1=3, \mathrm{df} 2=423)\end{array}$ & Keputusan \\
\hline 1,357 & 2,680 & \multirow{3}{*}{$\mathrm{H}_{0}$ diterima } \\
\hline $\mathrm{A}$ & $p$-value & \\
\hline 0,05 & 0,255 & \\
\hline
\end{tabular}

Hipotesa 2, 3, dan 4 diuji menggunakan uji Mann-Whitney U dengan tingkat risiko $\alpha=0,05$. Kriteria pengujian pada uji Mann-Whitney $\mathrm{U}$ adalah jika $p$-value $\leq \alpha$, maka $\mathrm{H}_{0}$ ditolak dan jika $p$-value $\geq \alpha$, maka $\mathrm{H}_{0}$ diterima (Corder \& Foreman, 2014). Dari uji Mann-Whitney U diperoleh hasil sebagai berikut: 
Tabel 3

Hasil Uji Mann-Whitney U atas Hipotesis 2, 3, dan 4

\begin{tabular}{ccc}
\hline $\mathrm{A}$ & $p$-value & Keputusan \\
\hline 0,05 & 0,108 & $\mathrm{H}_{0}$ diterima \\
\hline 0,05 & 0,358 & $\mathrm{H}_{0}$ diterima \\
\hline 0,05 & 0,079 & $\mathrm{H}_{0}$ diterima \\
\hline
\end{tabular}

Sama seperti Hipotesis 1, pengujian Hipotesis 5 dilakukan menggunakan uji Kruskal-Wallis H untuk k-independent samples dan uji one way ANOVA on rank. Dari uji Kruskal-Wallis $\mathrm{H}$ dan one way ANOVA on rank atas Hipotesis 5 diperoleh hasil sebagai berikut:

Tabel 4

Hasil Uji Kruskal-Wallis $\mathbf{H}$ atas Hipotesis 5

\begin{tabular}{|c|c|c|}
\hline $\mathrm{A}$ & $p$-value & Keputusan \\
\hline 0,05 & 0,019 & $\mathrm{H}_{0}$ ditolak \\
\hline \multicolumn{3}{|c|}{$\begin{array}{c}\text { Tabel } 5 \\
\text { Hasil Uji one way ANOVA on rank atas Hipotesis } 5\end{array}$} \\
\hline F Hitung & $\begin{array}{c}\text { F Tabel } \\
(\mathrm{df} 1=2, \mathrm{df} 2=297)\end{array}$ & Keputusan \\
\hline 0,307 & 3,072 & \multirow{3}{*}{$\mathrm{H}_{0}$ diterima } \\
\hline A & p-value & \\
\hline 0,05 & 0,736 & \\
\hline
\end{tabular}

Perbedaan hasil uji atas ketiga tabel mortalita CSO yang diuji secara bersamasama dengan menggunakan dua metode tersebut muncul karena variasi hasil uji dua tabel mortalita CSO yang diuji secara terpisah dengan menggunakan uji Mann-Whitney U. Dari uji Mann-Whitney U atas Hipotesis 6, 7, dan 8 diperoleh hasil sebagai berikut:

Tabel 6

Hasil Uji Mann-Whitney U atas Hipotesis 6, 7, dan 8

\begin{tabular}{ccc}
\hline A & $p$-value & Keputusan \\
\hline 0,05 & 0,040 & $\mathrm{H}_{0}$ ditolak \\
\hline 0,05 & 0,008 & $\mathrm{H}_{0}$ ditolak \\
\hline 0,05 & 0,428 & $\mathrm{H}_{0}$ diterima \\
\hline
\end{tabular}

Sebagai perbandingan, rata-rata tingkat kematian tabel mortalita CSO 1980 akan dibandingkan dengan rata-rata tingkat kematian TMI I. Pemilihan tabel mortalita CSO 1980 dan TMI I didasari pertimbangan tahun penerbitan kedua tabel mortalita yang berdekatan. Tabel mortalita CSO 1980 dirilis tahun 1980 sedangkan TMI I dirilis tahun 1993. Kedua tabel mortalita tersebut 'hanya' terpaut 13 tahun. 
Setelah dilakukan pengujian menggunakan uji Mann-Whitney U terbukti bahwa kedua tabel mortalita CSO 1980 dan TMI I tidak memiliki perbedaan yang nyata pada rata-rata tingkat kematian.

Tabel 7

Hasil Uji Mann-Whitney $U$ atas Hipotesis 9

\begin{tabular}{ccc}
\hline $\mathrm{A}$ & $p$-value & Keputusan \\
\hline 0,05 & 0,250 & $\mathrm{H}_{0}$ diterima \\
\hline
\end{tabular}

\section{Kesimpulan}

Berdasarkan hasil uji nonparametrik dan one way ANOVA on rank, tidak ditemukan perbedaan rata-rata tingkat kematian yang nyata pada keempat tabel mortalita TMI I hingga IV yang dirilis dalam rentang waktu 26 tahun sejak tahun 1993 hingga 2019. Pada tabel mortalita CSO diperoleh hasil yang bervariasi. Rata-rata tingkat kematian tabel mortalita CSO 1941 berbeda secara nyata dengan rata-rata tingkat kematian tabel mortalita CSO 1958 dan CSO 1980. Pada perbandingan tabel mortalita CSO 1958 dan CSO 1980 tidak ditemukan perbedaan yang nyata pada rata-rata tingkat kematian.

Semakin jauh jarak penerbitan tabel mortalita CSO (CSO 1941 dan CSO 1980 memiliki $p$-value paling kecil) semakin kecil $p$-value atau perbedaan rata-rata tingkat kematian semakin nyata. Hal yang sama juga terjadi pada tabel mortalita TMI (TMI I dan TMI IV memiliki $p$-value paling kecil).

Perbandingan silang antara tabel mortalita Amerika Serikat dan Indonesia, ratarata tingkat kematian pada CSO 1980 dan TMI I tidak berbeda secara nyata. Implikasi dari hasil uji ini adalah penggunaan tabel mortalita pada pembuatan produk asuransi tidak harus secara ketat menggunakan salah satu tabel mortalita saja. Pada era sebelum diterbitkannya TMI I, hampir semua perusahaan asuransi jiwa di Indonesia menggunakan tabel mortalita CSO milik Amerika Serikat, baik CSO 1941, CSO 1958 dan CSO 1980 untuk merancang produk-produk asuransi jiwa. Bahkan pada saat TMI I diperkenalkan, masih banyak perusahaan asuransi yang menggunakan tabel mortalita CSO 1958 dan CSO 1980. Berdasarkan hasil uji pada paper ini, penggunaan tabel mortalita CSO 1958 dan CSO 1980 pada saat-saat awal diperkenalkannya TMI pertama di Indonesia, tidak memberikan hasil yang berbeda secara signifikan.

Penelitian lanjutan dapat dikembangkan untuk menguji apakah penggunaan tabel mortalita yang berbeda-beda menghasilkan rata-rata tingkat premi bersih yang berbedabeda pada asuransi jiwa seumur hidup, asuransi jiwa berjangka dan asuransi jiwa dwiguna dengan asumsi tingkat bunga yang sama dan masa asuransi yang sama. 


\section{BIBLIOGRAFI}

Collett, David. (2015). Modelling survival data in medical research. CRC press.

Corder, Gregory W., \& Foreman, Dale I. (2014). Nonparametric statistics: A step-bystep approach. John Wiley \& Sons.

Dickhaus, Thorsten. (2018). Theory of nonparametric tests. Springer.

Hair, J. F., Anderson, R. E., Babin, B. J., \& Black, W. C. (2010). Multivariate data analysis: A global perspective (Vol. 7): Pearson Upper Saddle River. NJ.

Hollander, Myles, Wolfe, Douglas A., \& Chicken, Eric. (2013). Nonparametric statistical methods (Vol. 751). John Wiley \& Sons.

Khmaladze, Estáte V. (2013). Statistical methods with applications to demography and life insurance. CRC Press.

Lundquist, Jennifer Hickes, Anderton, Douglas L., \& Yaukey, David. (2014). Demography: the study of human population. Waveland Press.

Macdonald, Angus S., Richards, Stephen J., \& Currie, Iain D. (2018). Modelling mortality with actuarial applications. Cambridge University Press.

Pitacco, Ermanno. (2014). Insurance Applications of Life Tables. Wiley StatsRef: Statistics Reference Online.

Siebert, Carl F., \& Siebert, Darcy Clay. (2017). Data analysis with small samples and non-normal data: Nonparametrics and other strategies. Oxford University Press.

Skiadas, Christos H., \& Skiadas, Charilaos. (2018). Demography and health issues: Population aging, mortality and data analysis (Vol. 46). Springer.

Smith, David, \& Keyfitz, Nathan. (2012). Mathematical demography: selected papers (Vol. 6). Springer Science \& Business Media.

Tesárková, Klára Hulíková, \& Kurtinová, Olga. (2018). Lexis in Demography. Springer.

Thomas, Richard K. (2018). Concepts, methods and practical applications in applied demography: an introductory textbook. Springer.

Wunsch, Guillaume, Mouchart, Michel, \& Duchêne, Josianne. (2013). The life table: modelling survival and death (Vol. 11). Springer Science \& Business Media. 